\title{
RELIABILITY-BASED APPROACH FOR RESIDUAL LIFE PREDICTION OF BRIDGES SUBJECTED TO EARTHQUAKE DEGRADATION
}

\author{
Maizuar $^{1)}$, Said Jalalul Akbar ${ }^{2)}$, Wesli ${ }^{3)}$, Burhanuddin ${ }^{4)}$ \\ Department of Civil Engineering, Universitas Malikussaleh, Aceh Utara, Indonesia \\ e-mail: maizuar@unimal.ac.id ${ }^{1)}$ jaakidani@gmail.com ${ }^{2}$, wesli@unimal.ac.id ${ }^{3}{ }^{3}$
}

DOI: http://dx.doi.org/10.29103/tj.v9i1.189

\begin{abstract}
Structural degradation caused by sudden damaging extreme events (e.g. earthquake) has significant impact on residual life of bridges and ultimately the collapse of bridges. This paper presents a reliability-based approach of a bridge subjected to shock degradation caused by earthquake events. In particular, this study develops a numerical procedure for assessing time dependent probability of failure to estimate the residual life a bridge. Key factors that govern the residual life of a bridge (e.g., damage size caused by earthquake shocks and loss of initial structural capacity) were investigated. The results of study show that both damage size caused by earthquake shocks and loss of initial structural capacity are key factors that govern residual life of a bridge.
\end{abstract}

Keywords: residual life, earthquake, shock degradation, bridge.

\begin{abstract}
Abstrak
Degradasi struktur akibat dari beban ekstrim yang merusak (seperti gempa) mempunyai pengaruh signifikan terhadap sisa umur layan jembatan bahkan menyebabkan keruntuhan jembatan itu sendiri. Paper ini mempresentasikan degradasi struktur jembatan akibat dari beban gempa dengan menggunakan pendekatan metode reliabilitas. Secara lebih khusus, studi ini mengembangkan prosedur numerik untuk menentukan probabilitas kerusakan dan memprediksi sisa umur layan jembatan. Faktor penting yang mempengaruhi sisa umur layan jembatan akibat dari beban gempa (seperti ukuran kerusakan struktur dan kehilangan kapasitas struktur awal akibat dari beban gempa) telah diteliti. Hasil studi menunjukkan bahwa ukuran kerusakan struktur dan kehilangan kapasitas struktur awal akibat dari beban gempa merupakan faktor yang mempengaruhi sisa umur layan jembatan.
\end{abstract}

Kata kunci: sisa umur layan, gempa bumi, degradasi beban shock, jembatan

\section{Introduction}

Being located in Southeast Asia region, surrounded by three earthquake plates (e.g., the Eurasian, Indonesia-Australian and Pacific plates), Indonesia is considered as one of the most earthquake prone countries in the world. It is estimated about ten percent of earthquakes occur in Indonesia and its vicinities each year (Merati and Surahman, 1998). Major seismic events in Indonesia, such as those occurring in Papua (2004, magnitude 7.1), Aceh (2004, magnitude 9.2) and Yogyakarta (2005, magnitude 6.5) have continued to demonstrate the 
devastating power of earthquakes, with destruction to have caused infrastructure damages (e.g., bridges) and losses of lives and properties (Sieh, 2004).

Bridges are critical transportation infrastructure networks and often subjected to several types of hazards (e.g., earthquakes). Ageing bridges infrastructure and dynamic effects caused by earthquake shocks could reduce the service life and ultimately the collapse of bridges. Estimating the lifetime of a bridge requires a model capable of predicting its performance over time, which depends on both external (e.g. environmental demands) and internal aspects (e.g. material degradation) and their relationship with the structural performance. Predicting the residual life of a bridge is challenging and involves estimation of the progressive damage accumulation due to ageing bridge (e.g. corrosion and degradation of bridge materials) and the immediate damage caused by extreme events (e.g. earthquakes) (Ausroads, 2004, Lacasse and Vanier, 1996).

Current life-cycle performance models of structures can be grouped into two broad categories: progressive deterioration and shock degradation. While progressive deterioration (e.g. corrosion) is a time-dependent phenomenon that continuously depletes at a rate over the structures lifetime, shock degradation (e.g. earthquakes) describe the sudden changes in the structural performance over small time intervals. Both deterioration mechanisms cause damage accumulation over time (Maizuar et al., 2017, Sánchez-Silva and Klutke, 2016). Previous studies on progressive deterioration of reinforced concrete structures have focused on chloride ingress that results in steel reinforcement corrosion, concrete creep, cracking and loss of bond and spalling (Melchers et al., 2008, Zhang et al., 2013). Numerous research has been carried out on mathematical models for shock degra ation (Barlow and Proschan, 1996, Nakagawa, 1985). A particular application of this model to earthquake damage of structures can be found in Sanchez-Silva and Rackwitz (Sanchez-Silva and Rackwitz, 2004). However, life-cycle of a bridge as a result of changes to a number of parameters (e.g. initial structural capacity and damage size caused by an earthquake shock) that govern its residual service life is not fully understood yet. Therefore, the purpose of this study is to develop a reliability approach to predict the residual life of a bridge subjected to earthquake shocks.

\section{Methods}

\subsection{Reliability analysis of a bridge subjected to earthquake shocks}

The design and operation of a system or a component requires estimating the future performance of the system, which implies evaluating the system's ability to operate successfully or at least at a desired level of performance in a specified condition during a certain period of time. This evaluation can be performed using reliability analysis (Sánchez-Silva and Klutke, 2016).

The term of reliability is used to describe how structures fail. It quantifies the probability that a structure will fulfil its design requirements. Reliability is also used to describe the ability of a structure or system to perform its intended function. It can be mathematically defined as the probability that a structure or system will continue to perform its intended function without failure for a specified period of time under the operating conditions encountered. However, the 
purpose of reliability analysis is not simply to estimate the probability of failure of structures, but rather to provide more information about failures to support making decisions that improve the structure's quality, safety and performance, and to reduce its cost (Sanchez-Silva et al., 2011, Aven and Jensen, 1999).

The reliability of a bridge throughout its lifetime is greatly affected by inservice loading, material deterioration (e.g., corrosion), and sudden damaging events (e.g., earthquakes). Both resistance and demand are time-dependent variables and they must be considered in the service-life prediction of deteriorating structures (Caprani et al., 2007, Val et al., 2000). Shock events (e.g., earthquakes) occur randomly in time and cause a random amount of damage. Thus, the damage of a structure can be modelled using marked point process which count the number of occurrence events in the interval $(0, t)$ (Riascos-Ochoa et al., 2014). Then, the amount of damage on a structure at a given time is the summation of each shock sizes (damage sizes). It should be noted that the shock size does not necessarily describe the intensity or hazard of the shock event but the damage subjected to the structure. In this case, the structural deterioration may occur due to a single shock or damage accumulation by a series of shock events.

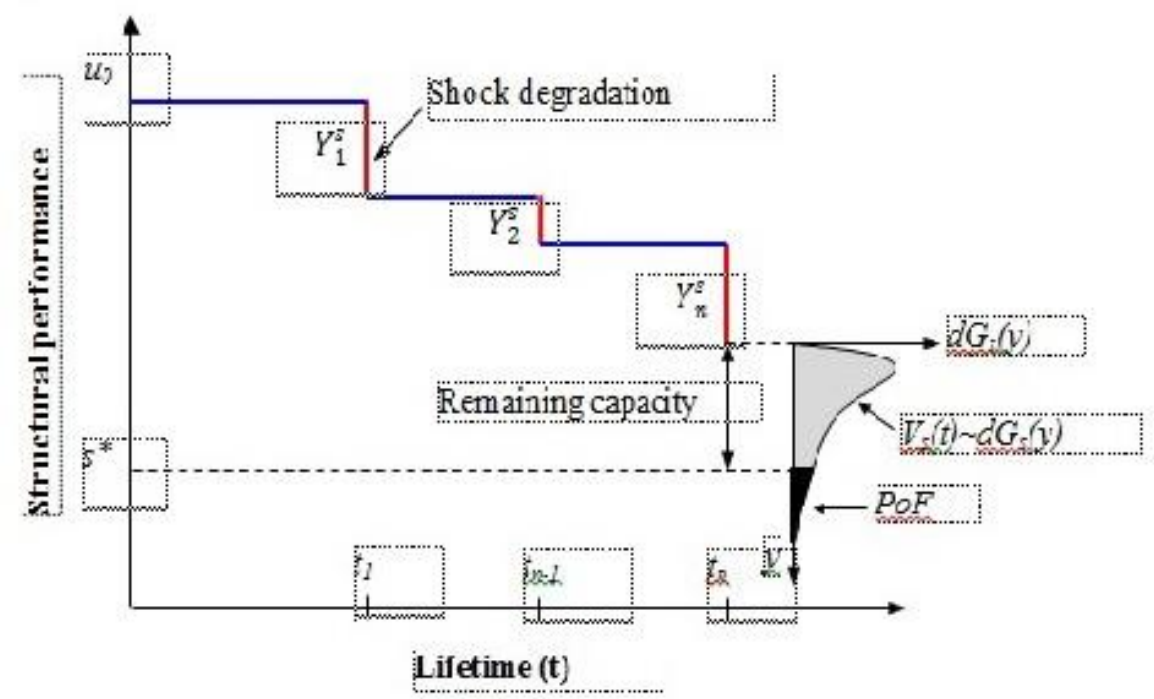

Figure 1 Shock-based degradation model

Source: Sánchez-Silva and Klutke, (2016)

If the damage of a structure resulting from a shock event $\left(Y_{i}^{s}\right)$ and the time interval between shocks $\left(X=\Delta t_{i}^{s}\right)$ are random variables, the damage accumulated up to time $t ; D_{s}(t)$ as a result of $N$ shock events can be computed as,

$$
D_{s}(t)=\sum_{i=0}^{N} Y_{i}^{s}
$$

Then, the remaining structural capacity $V_{s}(t)$ can be obtained,

$$
V_{s}(t)=u_{0}-D_{s}(t)-s^{*}
$$


Where, $u_{0}$ is the structural initial capacity and $s^{*}$ the limit state threshold value. Structural intervention (e.g., preventive or maintenance) is required when $V_{s}(t)<0$. If $V_{s}(t)$ follows a known probability distribution $\left(G_{s}\right)$, the reliability of a structure $\left(R_{S}\right)$ is given by,

$$
R_{s}=\int_{0}^{V_{s}(t)} G_{s}(y) d y
$$

The reliability of a structure can also be computed in term of probability of failure $\left(P_{s}\right)$ as follow,

$$
P_{s}(t)=1-\int_{0}^{V_{s}(t)} G_{s}(y) d y
$$

\subsection{Numerical procedure}

By assuming time between shocks $\left(X_{\mathrm{i}}\right)$ and damage size $\left(Y_{\mathrm{i}}\right)$ are independent and identically distributed (iid), as well as exponentially distributed, simulation process involves the following steps:

1. Set accumulated deterioration $D=0$; total time $S_{n}=0$; residual capacity $V=$ $u_{0}-a^{*}$

2. Obtain the time between shocks $\left(X_{i}\right)$ from exponential distribution; total time $S_{i}=S_{i-1}+X_{i}$

3. Obtain the damage size $\left(Y_{\mathrm{i}}\right)$ at total time $S_{i}$ from exponential distribution;

4. Compute damage accumulation $D=D+Y_{\mathrm{i}}$;

5. Compute residual capacity $V=V-D$;

6. Go to step (2) until reaching a particular time point $\left(t_{n}\right)$;

7. Probability of failure at time $t_{n}$

\subsection{Illustrative application}

Consider a case of a bridge that is subject to shock-based degradation (e.g. earthquake) that occurs randomly in time. The inter-arrival times of disturbances are exponentially distributed with mean $=10$ years. Suppose the initial capacity of a bridge is $u_{0}=100 \%$ with a threshold limit $a^{*}=25 \%$. Estimate the probability an intervention is required if the shock size is exponentially distributed with an average rate $\lambda=2 \%$. Assume the remaining structural capacity is governed by an exponential distribution $W(y, \theta)$ with an average rate $\theta=0.05$. A MATLAB code was developed and the average values of probability failure of the bridge were calculated.

\section{Results and discussion}

The approach for predicting residual life of bridges subjected to earthquake shocks was implemented using MATLAB code. The simulation was carried out to generate various sample paths of shock degradation process. The calculated probability of failure of a bridge with time was plotted. In this study, the average of the degradation process was used for further analysis. The random sample paths showing remaining capacity and probability of failure of a bridge subjected to shock degradation with damage size $Y_{i}$ of $2 \%$ and $X_{i}$ of 10 years are shown in Figure 2 and 3. 
The effect of damage sizes (e.g., 2\%, 15\% and 40\%) and time between shocks (e.g., 10 years, 50 years and 100 years) on time-dependent probability of failure of the bridge is shown in Figure 4. It can be seen that the accumulated damage due to the increase of damage sizes caused by earthquakes has significant impacts on the probability of failure and led to a reduced of bridge residual life. In comparison to damage size of $2 \%$, the damage sizes of $15 \%$ and $40 \%$ could reduce the bridge residual life of around $38 \%$ and $51 \%$, respectively.

Structural degradation of bridges is also associated with structural or functional deficient state due to bridges ageing. In this case, the bridges invariably subjected to certain level of deterioration and so the initial capacity of a bridge decreases. Comparison of the probability of failure of the bridge under different initial structural capacity is shown in Figure 5. The results show that the loss of initial structural capacity has significant impact that governs the bridge residual life.

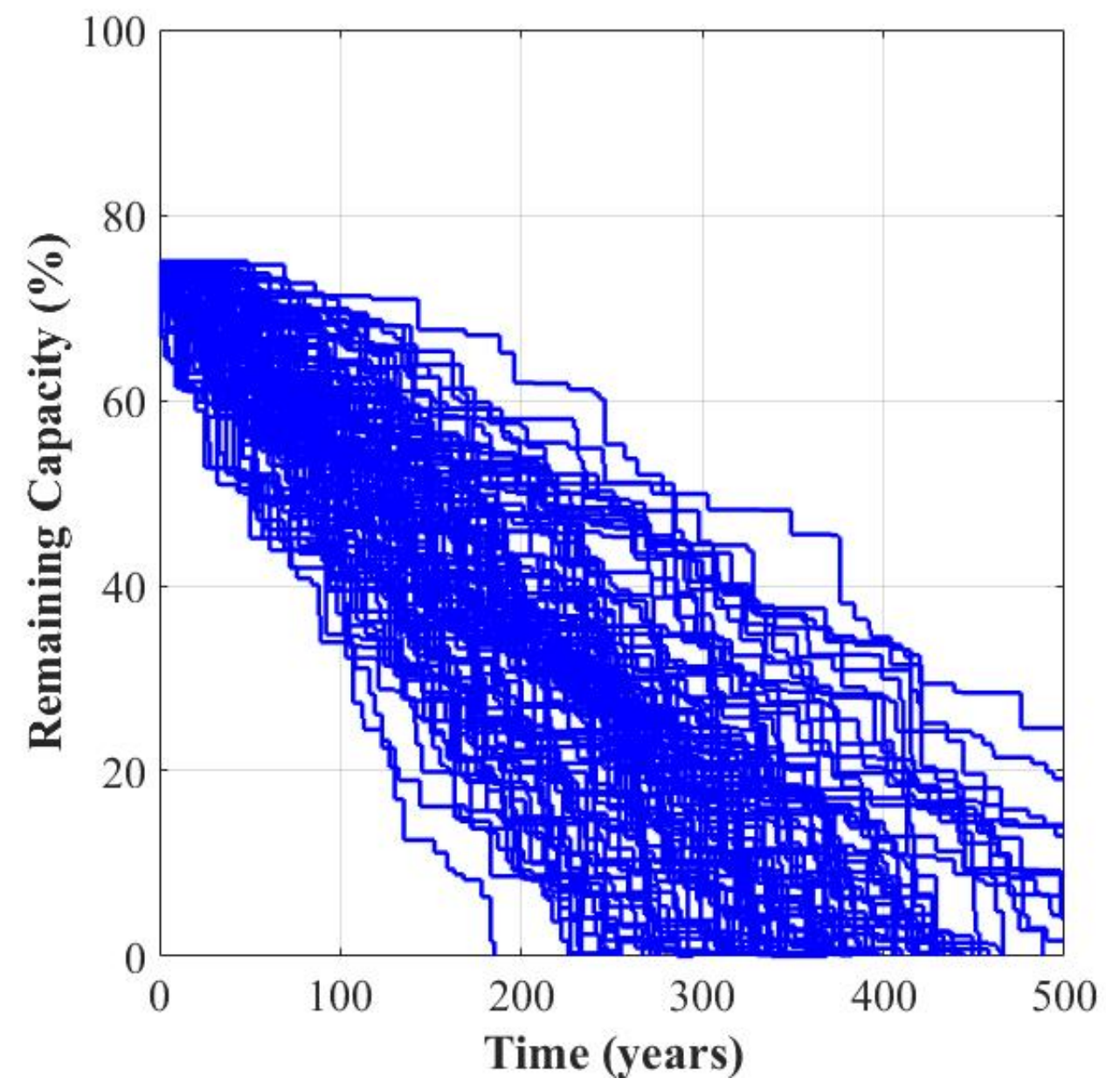

Figure 2 Random sample paths showing the remaining capacity of a bridge subjected to earthquake shocks (damage sizes of $2 \%$ and time between shocks of 10 years 


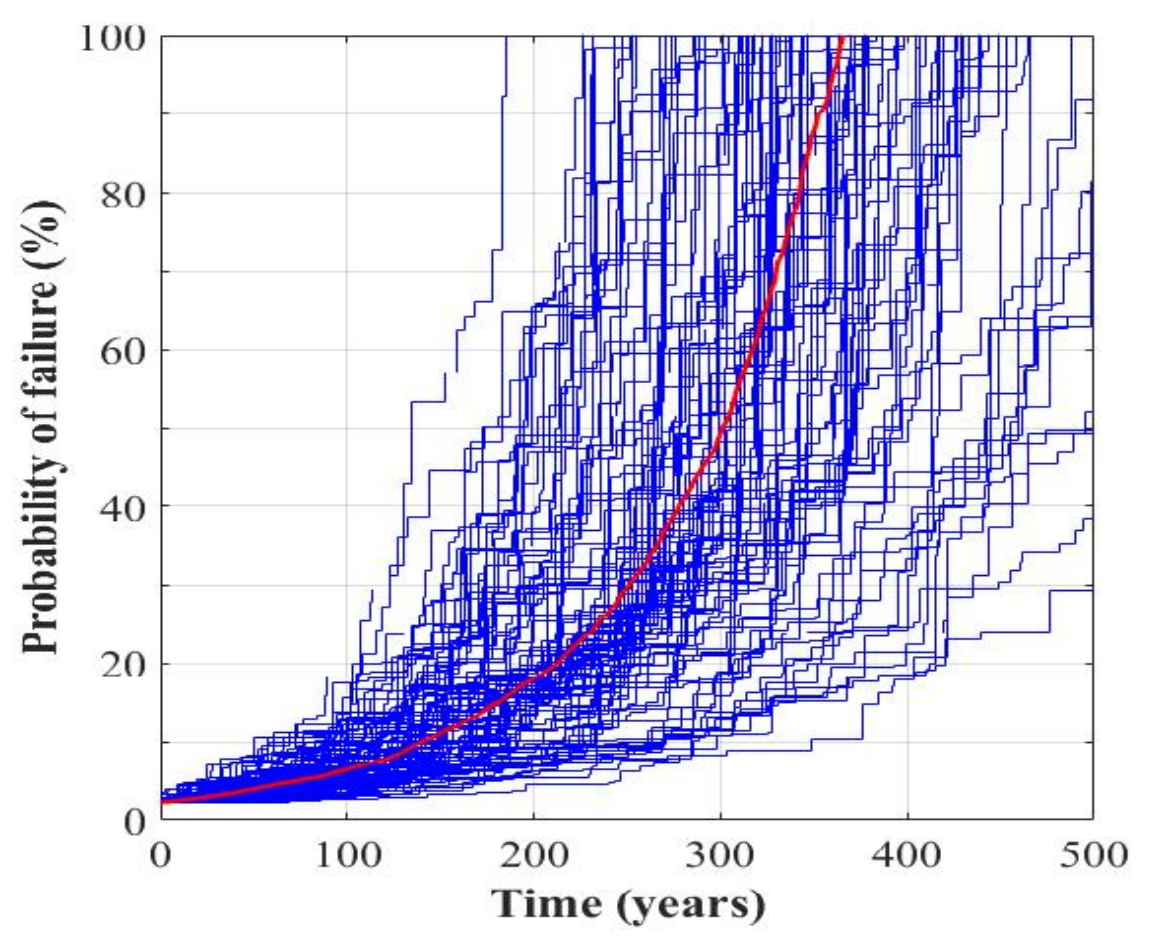

Figure 3. Random sample paths showing the probability of failure of a bridge subjected to earthquake shocks (damage sizes of $2 \%$ and time between shocks of 10 years). The calculated average probability of failure is shown by red line.

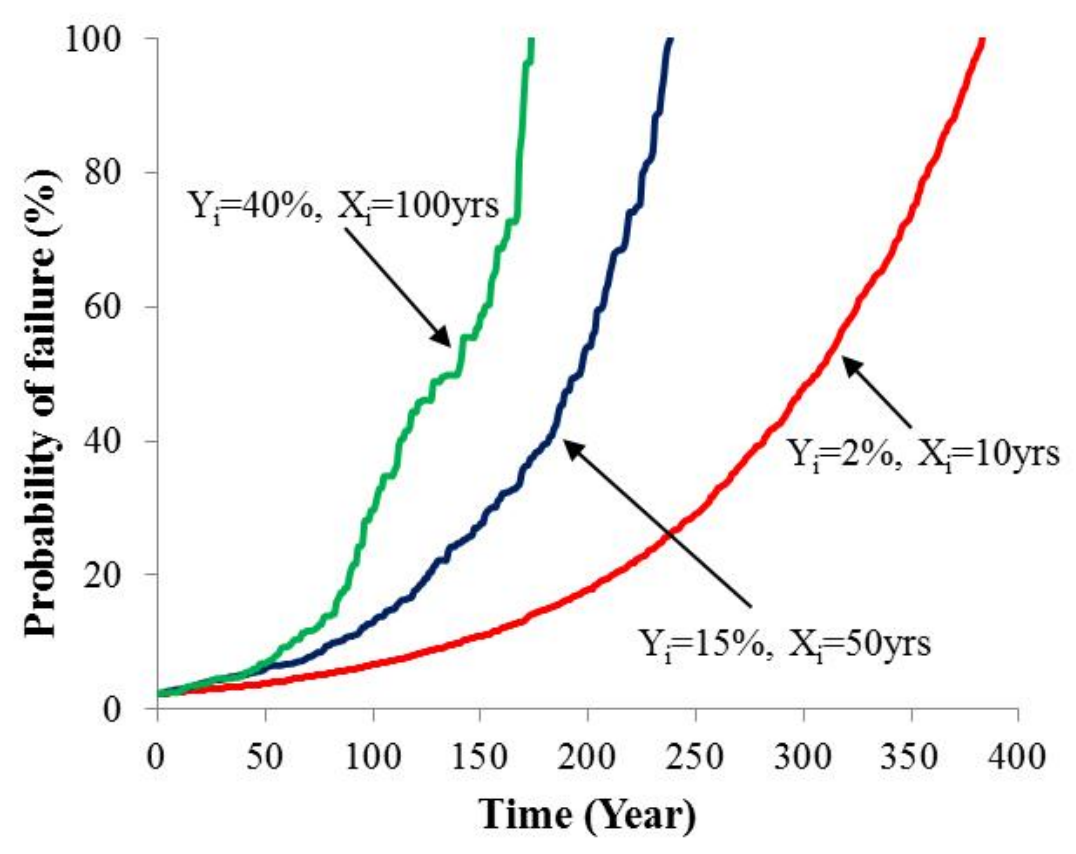

Figure 4. Effect of damage sizes and times between shocks on bridge residual life 


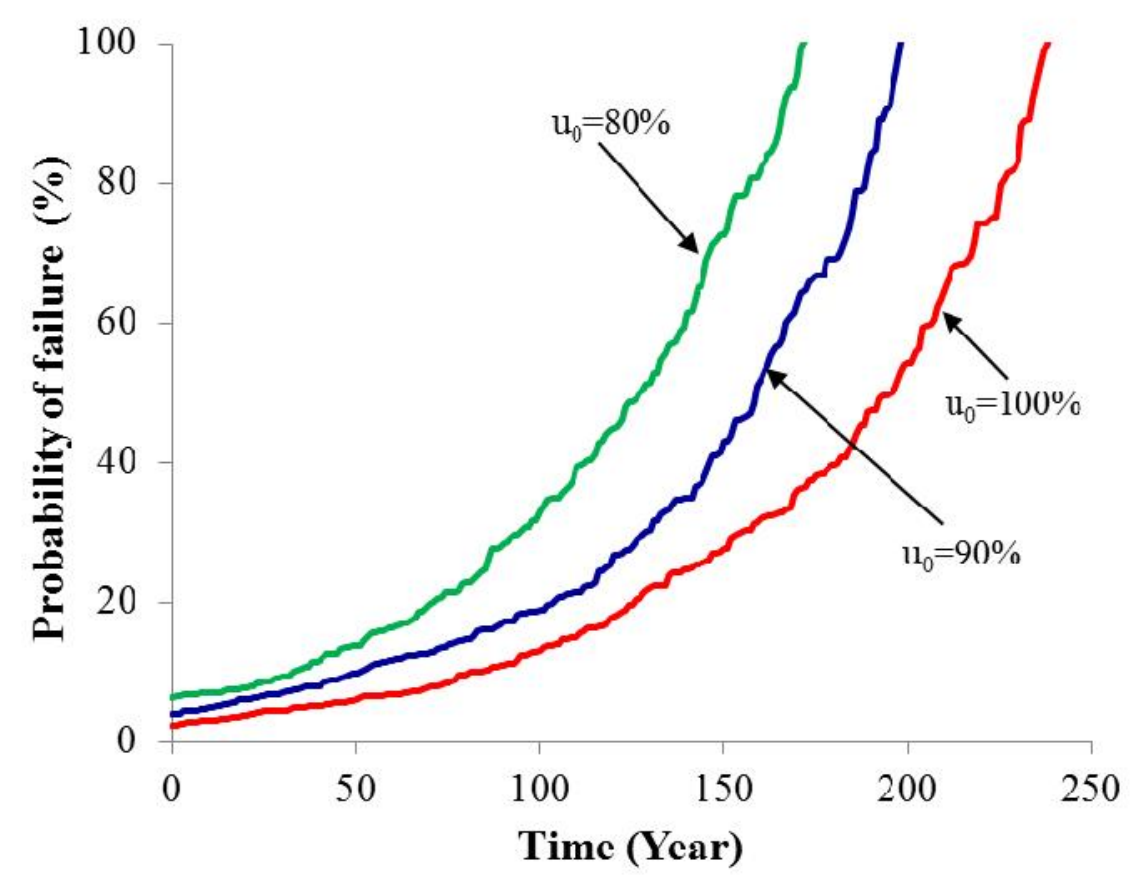

Figure 5: Effect of loss of structural capacity on bridge residual life

\section{Conclusions}

In this study, a numerical procedure for assessing the bridge residual life subjected to earthquake shocks was presented. In particular, this study considers shock events (e.g., earthquakes) occur randomly in time and cause a random amount of damage. The reliability analysis to compute the time-dependent probability of failure as well as to estimate the bridge residual life was described. Then, a numerical procedure using MATLAB code was developed. Finally, an illustrative example of bridge subjected to earthquake shocks was computed. Several key parameters that govern the bridge residual life was simulated. The results show that both damage size caused by earthquake shocks and loss of initial structural capacity have significant impact that governs the residual life of bridges.

It was shown that the developed reliability-based approach can be used to predict the residual life of a bridge subjected to earthquake shocks. However, the damage sizes of a bridge caused by earthquake shocks used in this study is based on a simple assumption. It is suggested that estimation the magnitude of bridge damage sizes as a result of earthquake shocks using shaking table tests or computational simulation.

\section{References}

Ausroads, 2004. Concrete durability-development of models to predict and extend the service life of concrete bridges. Sydney.

Aven, T., Jensen, U., 1999. Stochastic models in reliability. New York, Springer.

Reliability-Based Approach For Residual Life Prediction Of Bridges Subjected To Earthquake Degradation - Maizuar, Said Jalalul Akbar, Wesli, Burhanuddin 
Barlow, R.E., Proschan, F., 1996. Mathematical theory of reliability. Philadelphia, PA, USA.

Caprani, C., Mcnally, C., O'brien, E., Bordallo-Ruiz, A., 2007. The structural reliability of bridges subject to time-dependent deterioration. In: Proceedings of the $11^{\text {th }}$ conference on civil, structural and environmental engineering computing. Stirling, Scotland.

Lacasse, M.A., Vanier, D.J., 1996. A review of service life and durability issues. In: The $7^{\text {th }}$ international conference on the durability of building materials and components. Stockholm, Sweden.

Maizuar, M., Zhang, L., Miramini, S., Mendis, P., Thompson, R.G., 2017. Detecting structural damage to bridge girders using radar interferometry and computational modelling. Struct Control Health Monit. 24. 1-6.

Melchers, R.E., Li, C.Q., Lawanwisut, W., 2008. Probabilistic modeling of structural deterioration of reinforced concrete beams under saline environment corrosion. Struc Saf. 30. 447-460.

Merati, W., Surahman, A., 1998. Research for Indonesian seismic design code update. In: Proceeding of Asia Pacific workshop on seismic design and retrofit of structures. 71- 82 .

Nakagawa, T., 1985. Continuous and discrete age-replacement policies. The Journal of the Operational Research Society. 36. 147-154.

Riascos-Ochoa, J., Sanchez-Silva, M., Akhavan-Tabatabaei, R., 2014. Reliability analysis of shock-based deterioration using phase-type distributions. Probabilist Eng Mech. 38. 88-101.

Sánchez-Silva, M., Klutke, G.-A., 2016. Reliability and life-cycle analysis of deteriorating systems. Springer.

Sanchez-Silva, M., Klutke, G.-A., Rosowsky, D.V., 2011. Life-cycle performance of structures subject to multiple deterioration mechanisms. Struct Saf. 33. 206-217.

Sanchez-Silva, M., Rackwitz, R., 2004. Socioeconomic implications of life quality index in design of optimum structures to withstand earthquakes. J Struct Eng. 130. 969-977.

Sieh, K., 2004. The science behind the Aceh earthquake. Caltech Media Relations.

Val, D.V., Stewart, M.G., Melchers, R.E., 2000. Life-cycle performance of RC bridges: Probabilistic approach. Comput-Aided Civ Infrastruct Eng.15. 1425.

Zhang, L., Mendis, P., Hon, W.C., Fragomeni, S., Lam, N., Song, Y., 2013. Effects of cyclic loading on the long-term deflection of prestressed concrete beams. Comput Concr. 12. 739-754. 